\title{
Prilaku Keluarga dalam Pemenuhan Kebutuhan Nutrisi pada Pasien Diabetes Militus di Kabupaten Bima
}

\author{
M. Ikbal ${ }^{1(\mathrm{CA})}$ \\ ${ }^{1(C A)}$ Mahasiswa Program Studi Magister Kesehatan Fakultas Kesehatan Universitas Qamarul Huda \\ Badaruddin Jln. H. Badruddin Bagu - Pringgarata - Lombok Tengah \\ e-mail: iqbal.bkd81@yahoo.co.id
}

\begin{abstract}
Meeting the nutritional needs of patients with diabetes mellitus is the main therapy of the five basic treatments of diabetes mellitus called diabetes mellitus diabetes psychology. The nutritional needs of patients with diabetes mellitus are based on the discipline of nutritional needs in patients with diabetes mellitus, namely meal schedule, type of food, and the amount of food. Dietary management for diabetic patients must be well known and implemented by diabetic patients to control nutrient intake that is appropriate to the body's needs. This research was conducted in Bima 2019. This type of research is a type of descriptive research in which the researcher wants to see an overview of the variables studied. Based on the purpose of this study using a cross sectional research design that is a study plan that measures research variables at the same time in a certain period of time. With a total sample of 37 respondents. The results of this study indicate that the selection of food ingredients, food processing, as well as the eating schedule of patients with diabetes mellitus on average have less knowledge. To families with diabetes mellitus expect to always provide tangible, hopeful and emotional support to family members suffering from diabataes miletus
\end{abstract}

\section{Keywords: Diabetes Militus, Foodstuffs, Food processing, Food serving}

\begin{abstract}
ABSTRAK
Pemenuhan kebutuhan nutrisi pada pasien Diabetes militus merupakan terapi utama dari lima dasar pengobatan diabetes militus yang dinamakan pentalogi terapi diabetes militus. Adapun kebutuhan nutrisi pada penderita Diabetes militus berpatokan pada disiplin kebutuhan nutrisi pada pasien diabetes militus yaitu Jadwal makan, Jenis makanan, dan Jumlah makanan. Manajemen diet bagi pasien diabetes harus diketahui dan dilaksanakan dengan baik oleh pasien diabetes untuk mengontrol asupan nutrient yang sesuai dengan kebutuhan tubuh.Penelitian ini telah dilaksanakan di Bima tahun 2019. Jenis penelitian ini termasuk jenis penelitian Deskriftif dimana peneliti ingin melihat suatu gambaran pada variabel yang diteliti. Berdasarkan tujuan penelitian desain yang digunakan adalah cross sectional yaitu rencana studi yang mengukur variabel penelitian dalam waktu yang bersamaan dalam kurun waktu tertentu. Dengan jumlah sampel sebanyak 37 responden. Hasil penelitian didapatkan bahwa bahan makanan, pengolahan makanan, serta pengaturan jadwal makan pasien diabetes militus rata - rata memiliki pengetahuan kurang. Kepada keluarga penderita penyakit diabetes melitus harapkan selalu memberikan dukungan yang nyata,pengharapan dan emosional kepada anggota keluarga penderita diabataes miletus
\end{abstract}

Kata Kunci : Diabetes Militus, Bahan Makanan; Pengolahan makanan; Penyajian makanan

\section{PENDAHULUAN}

Manajemen diet bagi pasien diabetes harus diketahui dan dilaksanakan dengan baik oleh pasien diabetes untuk mengontrol asupan nutrient yang sesuai dengan kebutuhan tubuh. Pemilihan jenis makanan yang tepat akan mempengaruhi kesehatan tubuh pasien diabetes melitus. Sudah banyak 
penelitian yang membahas tentang efek berbagai jenis makanan terhadap stabilitas, kontrol, atau yang mempengaruhi kadar glukosa darah. Kafein contohnya, dipahami sebagai salah satu yang dapat menurunkan glukosa darah walau belum dapat dikatakan dapat mempengaruhi kadar insulin seperti saat melakukan aktivitas (Alexandria, AV, ADA, 2006)

Peran keluarga dalam penanganan pasien diabetes millitus masih belum optimal yang disebabkan oleh kurangnnya informasi yang diperoleh keluarga tentang penangan atau pengelolaan makanan pada pasien diabetes militus sehingga mengurangi peran keluarga dalam menangani pengelolaan anggota keluarga dengan diabetes militus.

Kebutuhan nutrisi dengan diet atau mengontrol nutrisi merupakan hal yang penting bagi klien dengan diabetes melitus. Tujuan yang paling penting dalam manajemen nutrisi dan diet adalah untuk mengotrol total kebutuhan kalori tubuh, intake yang dibutuhkan, mencapai kadar serum lipid normal. Kompoisi kebutuhan nutrisi pada diet diabetes melitus adalah kebutuhan kalori, karbohidrat, lemak, protein dan serat. Kebutuhan kalori tergantung dari berat badan, jenis kelamin, usia, aktivitas fisik untuk menentukan jumlah kalori dalam tubuh, sedangkan kebutuhan karbohidrat merupakan komponen terbesar dari kebutuhan kalori tubuh, yaitu sekitar 50\% sampai 60\%, sedangkan kebutuhan protein untuk adekuatnya cdangan protein, diperlukan kira-kira $10 \%$ sampai $20 \%$ dari kebutuhan kalori atau 0,8 $\mathrm{g} / \mathrm{kg} / \mathrm{hari}$, sedangkan kebutuhan lemak kurang dari 30\% dari total kalori, sebaiknya dari lemak nabati dan sedikit dari lemak hewani, sedangkan kebuuhan serat dibutuhkan sekitar 20 sampai 35 g/hari dari berbagai bahan makanan atau rata-rata $25 \mathrm{~g} / \mathrm{hari}$.

Dari survey awal Di Desa Monggo Kecamatan Madapangga Kabupaten Bima di dapatkan pada tahun 2016 jumlah penderita diabetes militus sebanyak 25 orang meningkat pada tahun 2017 sebanyak 32 orang dan pada tahun 2018 jumlah penderita diabetes militus sebanyak 37 orang (Data Puskesmas Dena, 2019). Kebutuhan nutrisi pada pasien diabetes militus sangat mempengaruhi kondisi pasien diabetes militus, penelitian yang dilakukan oleh Robinson pada tahun 2006 terhadap 19 pasien diabetes militus menyimpulkan bahwa dukungan keluarga merupakan faktor yang paling utama dalam pemenuhan kebutuhan nutrisi klien dan mempengaruhi kualitas hidup pasien diabetes militus. Selanjutnya Grifiin At Dalan Skrabec 2006 pada sebuah studi longitudinal melakukan investigasi peran keluarga terhadap status kesehatan pasien menemukan hubungan yang sangat kuat antara peran keluarga dengan status kesehatan pasien dengan diabetes militus dalam mempertahankan kualitas hidupnya.

Pemenuhan kebutuhan nutrisi pada pasien Diabetes militus merupakan terapi utama dari lima dasar pengobatan diabetes militus yang dinamakan pentalogi terapi diabetes militus. Adapun kebutuhan nutrisi pada penderita Diabetes militus berpatokan pada disiplin kebutuhan nutrisi pada pasien diabetes militus yaitu Jadwal makan, Jenis makanan, dan Jumlah makanan. ( Notoatmodjo, 2003)

\section{METODOLOGI}

Jenis penelitian ini termasuk jenis penelitian Deskriftif dimana peneliti ingin melihat suatu gambaran pada variabel yang diteliti. Berdasarkan tujuan penelitian desain yang digunakan adalah cross 
sectional yaitu rencana studi yang mengukur variabel penelitian dalam waktu yang bersamaan dalam kurun waktu tertentu.

\section{HASIL}

Hasil penelitian pada responden penderita Diabetes militus berdasarkan disiplin pemenuhan kebutuhan nutrisi yang meliputi jadwal makan, jenis makanan, dan pengolahan makanan dapat dilihat pada tabel berikut

Tabel Distribusi Frekuensi Responden Berdasarkan Perilaku Pemenuhan Kebutuhan Nutrisi yang meliputi Jadwal Makan, Jenis Makanan, dan Jumlah Makanan di Desa Monggo Kecamatan Madapangga Kabupaten Bima Juni $2019(\mathrm{n}=37)$

\begin{tabular}{|c|c|c|c|}
\hline No & Karakteristik & Frekwensi & $\%$ \\
\hline 1. & $\begin{array}{l}\text { Pemilihan bahan makanan : } \\
\text { - } \quad \text { Baik } \\
-\quad \text { Cukup } \\
-\quad \text { Kurang }\end{array}$ & $\begin{array}{c}4 \\
11 \\
22\end{array}$ & $\begin{array}{l}10.8 \\
29.7 \\
59.5\end{array}$ \\
\hline 2. & $\begin{array}{ll}\text { Pengolahan bahan makanan } \\
\text { - } & \text { Baik } \\
- & \text { Cukup } \\
- & \text { Kurang }\end{array}$ & $\begin{array}{l}4 \\
14 \\
19\end{array}$ & $\begin{array}{l}10.8 \\
37.8 \\
51.4\end{array}$ \\
\hline 3. & $\begin{array}{ll}\text { Jadwal makan } \\
\text { - } & \text { Baik } \\
- & \text { Cukup } \\
- & \text { Kurang }\end{array}$ & $\begin{array}{c}4 \\
9 \\
24\end{array}$ & $\begin{array}{l}10.8 \\
24.3 \\
64.9\end{array}$ \\
\hline
\end{tabular}

Berdasarkan tabel diatas responden terbanyak memiliki perilaku yang kurang tentang cara memilih bahan makanan bagi penderita diabetes militus yaitu sebanyak $59.5 \%$, demikian juga dengan pengolahan bahan makanan bagi penderita diabetes militus sebagian besar dalam kategori kurang $(51,4 \%)$ serta dalam hal pengaturan jadwal makan bagi penderita diabetes militus mayoritas dalam kategori kurang $(64.9 \%)$.

\section{PEMBAHASAN}

Dari hasil penelitian didapatkan bahwa pemilihan bahan makanan, pengolahan bahan makanan, serta pengaturan jadwal makan penberita diabetes militus rata - rata memiliki perilaku kurang hal ini disebabkan oleh masih belum paham dan tahu tentang pengaturan diet yang baik dan benar pada pasien diabetes militus. Informasi tentang diet diabetes militus perlu didapatkan guna menunnjang perbaikan kesehatan penderita diabetes militus, adapun penyebab responden kurang pengetahuan disebabkan oleh masih minimnnya informasitentang kesehatan khusunya pasien diabetes militus, dimana pengetahuan baik akan menunjang pemilihan, pengolhan dan pengaturan jadwal makan pasien diabetes militus yang benar pula. Informasi kesehatan sebenarnya dapat di peroleh melalui media seperti TV, radio dan majalah, dengan demikian pengetahuan itu bisa didapat melalui pendidikan formal maun informal, Bloom Mengatakan bahwa sebelum individu dapat memahai sesuatu terlebih dahulu individu mendapat pengetahuan. 
Banyak hal yang mempengaruhi tingkat pengetahuan responden seperti umur dan pendidikan. Seperti yang sudah kita ketahui, umur dapat mempengaruhi pengetahuan seseorang, dengan kata lain semakin muda usia seseorang maka semakin rendah pengetahuannya sebaliknya semakin tua usia seseorang maka semakin tinggi pengetahuannya. Usia merupakan tingkat kedewasaan seseorang. Semakin dewasa, tingkat kematangan dan kekuatan seseorang akan lebih besar dalam berfikir dan bekerja. Dikarenakan pengalaman hidup yang telah di lewatinya Dari pemahaman yang dimiliki responden dapat dituangkan dalam melakukanpengaturan diet pada pola makan responden sehari - hari. Maka dapat disimpulkan responden yang mempunyai pengetahuan yang baik tentang diet Diabetes Militus akan berkorelasi positif terhadap sikapnya dalam pengaturan pola diet diabetes militus. hal ini berarti sikap responden ditentukan oleh pengetahuan, pengetahuan yang baik akan menghasilkan sikap yang baik juga.

\section{KESIMPULAN}

Perilaku pemenuhan kebutuhan nutrisi yang meliputi jadwal makan, jenis makanan, dan jumlah makanan di Desa Monggo Kecamatan Madapangga Kabupaten Bima masih dalam katergori kurang. Oleh karena itu disarankan kepada petugas kesehatan masyarakat agar memberikan pendidikan kesehatan kepada penderita dan keluarganya tentang tata cara pemenuhan kebutuhan nutrisi bagi penderita diabetes mellitus.

\section{DAFTAR PUSTAKA}

Akhmad, B.S. Eri Yanuar. 2011. Diet Sehat Untuk Remaja. Yogyakarta: Kanius.

Almatsir. 2010. Prinsip Dasar Ilmu Gizi . PT Gramedia Pustaka Utama. Jakarta: Salemba Medika.

Arikunto. 2006. Prosedur Penelitian Suatu Pendekatan Praktik. Jakarta: Rineka Cipta

Arixs. 2006. Metodologi Penelitian Pendidikan. Bandung: Pustaka Setia.

Dalami, Ermawati dkk. 2009. Asuhan Keperawatan Jiwa Dengan Masalah Psikososial. Jakarta: CV. Trans Info Media.

Dieny, Fitra Fillah. 2014. Permasalahan Gizi Pada Remaja Putri. Jakarta: Graha Ilmu.

Hasibuan, Melayu.S.P. 2014. Manajemen Sumber Daya Manusia (Edisi Revisi) Jakarta: Bumi Askara.

Ircham. 2008. Pendidikan Kesehatan Bagian Dari Promosi Kesehatan. Yogyakarta: Fitramaya

Keliat Dkk. 2011. Proses Keperawatan Kesehatan Jiwa. Edisi 2. Jakarta: Salemba Medika.

Kementrian Kesehatan. 2013. Riskesdas.

Mappiare. AT, Andi. 2008. Pengantar Konseling Dan Psikoterapi. Jakarta: PT Raja Grafindo Persada.

Mubarak. 2006. Ilmu Keperawatan Komunitas Pengantar Dan Teori. Buku 1. Jakarta: Salemba Medika.

Notoatmojo, Soekidjo. 2012. Metodologi Penelitian Kesehatan. Edisi Revisi. Jakarta: Rineka Cipta. 
Ikbal (2020).

Nursalam. 2012. Konsep Dan Penerapan Metodologi Penelitian Ilmu Keperawatan Edisi 2. Jakarta: Salemba Medika.

Siti K. 2004. Psikologi Perkembangan. Yogyakarta.

Soegih, Rachmad. 2009. Obesitas Permasalahan Dan Terapi Praktis. Jakarta. CV Sagung Seto.

Subhan. 2014. Skripsi Tentang Hubungan Dukungan Keluarga Dengan Citra Diri Pada Remaja Obesitas di SMK Widya Praja Ungaran.

Tarwoto, Ns, S.Kep, M.Kep. (2012). Keperawatan Medikal Bedah. Gangguan sistem endokrin. Edisi 1. Jakarta: Trans Info Media

Utami. 2013. Diet Aman dan Sehat Dengan Helbal. Jakarta: FMedia 